\title{
Tanymastix stagnalis Linn. and its occurrence in Norway.
}

\author{
By
}

Robert Gurney M. A. (Norfolk).

In these days it is necessary to use much circumspection in referring to any European species of Phyllopod, since so many changes have been made recently in their nomenclature: It is important, therefore, to make clear in the first instance to what species I am alluding and to justify its identification with the species described by Linnaeus. Now Linnaeus, in his Fauna Suecica, describes one species only of Branchipodidae under the name of Cancer stagnalis, and, in his Systema Naturae, he gives as a synonym of it Schaeffer's "Apus pisciformis"1). The description given is inadequate to deternine by itself to what species he refers, with the exception that the colour of the egg-sac as there given is certainly not the same as in Schaeffers's species ${ }^{2}$. We have the authority of Prof. Lilljeborg that one species of Branchipod occurs commonly near Upsala and that this species is not the same as that described by Schaeffer, which is not known to occur in Sweden at all. We have therefore this dilemma; - Either Linnaeus overlooked a rather conspicuous animal which was common in his own neighbourhood and, in place of it, recorded as a member of the Swedish fauna a species which does not occur in Sweden; or he was in error in supposing that the two species described by himself and by Schaeffer were identical. Such an error as the latter is by no means unusual, whereas the first alternative seems to me incredible. It is necessary therefore to conclude, in spite of the arguments of Abonyi and of

1) The bibliographical facts have been stated by Abonyi. Int. Rev. ges. Hydrob. und Hydrog. Suppl. zu Bd. VI, p. 13, 1913, so that it is not necessary for me to quote the exact references and descriptions.

2) Simon. Ann. Soc. Entom. France (6) VI, 1886. p. 416. 
Daday ${ }^{1}$, that the specific name stagnalis Linn. was correctly applied by Lilljeborg and by Simon to that Phyllopod which was first adequately described by Guerin as Branchipus lacunae, and it is that species which I have here referred to as Tanymastix stagnalis Linn.

I should like to take this opportunity of calling attention to Dr. de Beauchamp's note ${ }^{2}$ ) in which he shows that the suppression by Daday of the name Chirocephalus diaphanus Prévost in favour of C. stagnalis Shaw is directly contrary to the International Rules of Nomenclature which Daday himself cites as "authority for the change. The title of Shaw's paper is "Description of the cancer stagnalis of Linnaeus", but he describes quite clearly, not the species referred to by Linnaeus, but one subsequently described by Prévost. Now Article 31 of the Rules lays down that "a specific name which undoubtedly rests on an error of identification cannot be retained for the misdetermined species even if the species in question are afterwards placed in different genera." So that Shaw's name falls to the ground and gives place - very fortunately - to that of Prévost.

I am indebted to Mr: Patrick Buxton for the opportunity of examining some specimens of Tanymastix stagnalis Linn. which were taken by him on August 14. 1913 in a pool at a height of about 3500 feet, above the Surendal in Norway. This pool is situated high above the tree line on the north side of a hill called Knyken, at the foot of a slope from which the snow had but recently melted. In company with the Tanymastix were a few specimens of the Ostracod Eucypris glacialis Sars, which is a species originally described from Spitzbergen, but also occuring in Novaia Zemlia, Finmark and in the highlands of of northern Sweden. The occurrence of Tanymastix stagnalis in such a locality is of great interest since it is a species practically confined to Central Europe bẹtween $46^{\circ}$ and $49^{\circ}$ N. Lat. (Daday), and even its occurrence in the lowlands of southern Sweden is regarded by Daday as exceptional. By its occurrence above the tree line in about Lat. $63^{\circ}$ in company with Eucypris glacialis, it places itself among the arctic species such as Branchinecta paludosa and Polyartemia forcipata. Its exceptional habitat does not seem to have induced any variation since I am unable to detect any important differences between my specimens and the description of typical specimens as given by Daday (Loc. cit. p. 330).

1) Daday. Ann. Sc. Nat. Ser. 9, IX, p. 317.

$\left.{ }^{2}\right)$ Int. Rev, ges. Hydrobiol, und Hydrogr. V, 1912, p. 381. 